some suppression of $\mathrm{GH}$ levels by a rise in blood glucose in acromegalic patients suggests that there might be only a partial deficiency of GHRIH or partially suppressible GH-RH in these patients.

The infusion of GHRIH resulted in impairment of glucose tolerance and a change in the shape of the blood glucose curve despite the marked reduction in $\mathrm{GH}$ levels. This can be explained by the observations that GHRIH impairs insulin secretion in response to glucose by a direct aotion on the pancreas, as reported in normal subjects by Alberti et al. (1973). We have also carried out further studies which confirm this effect. Possibly the reduotion in insulin response to glucose and the impairment of secretion of thyroid-stimulating hormone after giving thyrotrophin releasing hormone (Hall et al., 1973) represent non-physiological responses to the large doses of GHRIH delivered to the general circulation. Clearly, however, they may have impontant implications if this hypothalamic hormone is to be used to treat diseases associated with excessive GH secretion. The production of impaired glucose tolerance curves in two patients by GHRIH and a rise in the blood glucose levels at 150 minutes in the other two suggest that the effects of the polypeptide with respect to pancreatic function and the gastrointestinal hormones need to be fully evaluated.

We wish to thank the nursing and technical staff of the Programmed Investigation Unit, Newcastle Royal Victoria Infirmary, and the metabolic ward, St. Bartholomew's Hospital, for their valuable help. The studies have been generously supported by the Joint Research Board of St. Bartholomew's Hospital and the Peel Medical Research Trust.

\section{References}

Alberta, K. G. M. M., et al. (1973). Lancet, 2, 1299.

Brazeau, P., et al. (1973). Science, 179, 77.

Coy, D. H., Coy, E. J., Arimura, A., and Schally, A. V. (1973). Biochemical and Biophysical Research Communications, 54, 1267.

Hall, R., et al. (1973). Lancet, 2, 581 .

Prange Hansen, Aa., Orskov, H., Seyer-Hansen, K., and Lundbaek, K. (1973). British Medical fournal, 3, 523 .

Schally, A. V. (1972). In The Hypothalamus and Pituitary in Health and Disease, ed. W. Locke and A. V. Schally, p. 242. Springfield, Illinois, Thomas. Siler, T. M., et al. (1973). Fournal of Clinical Endocrinology and Metabolism,
37, 632.

\title{
Management of Patients with Urinary Calculi
}

\author{
S. J. A. POWIS， J. BLACK， J. A. MACDOUGALL， J. W. CLEWS
}

British Medical fournal, 1974, 1, 355-357

\section{Summary}

A retrospective survey was made of 305 patients with proved urinary calculi. When those patients with a solitary stone were compared with those with multiple stones no diagnostically helpful difference was noted in the prevalence of abnormal serum or urine biochemistry, urinary infection, or anatomical abnormality of the urinary tract. The same was true of the stone composition and the need for surgery. It seems that neither routine radiological examination nor regular follow-up is likely to help identify patients whose stones are going to recur.

\section{Introduction}

Figures given for the prevalence of urinary calculi vary with the type of survey carried out. Ahlgren and Lorsted (1965), who studied all social groups in a large geographical area, reported the presence of urinary calculi in 80 per 100,000 of the population, whereas Larsen and Philip (1962), in a survey of Danish doctors, found a prevalence rate of 8,719 per 100,000 . However, the overall frequency of urinary stones, and hence the work load on stone clinics, does seem to be increasing.

The frequency of recurrence is also variable, some authors finding that $85-90 \%$ of patients suffer from solitary stones (Baker and Connolly, 1956; Garvey and Boyce, 1956); whereas Williams (1968) reported that $75 \%$ of patients with a urinary stone will form another.

Royal Hospital, Wolverhampton

S. J. A. POWIS, F.R.c.s., Senior Surgical Registrar, (Now Lecturer in Surgery, University of Birmingham)

J. BLACK, F.R.C.s., Surgical Registrar

J. A. MACDOUGALLL, M.CHIR., F.R.c.s., Consultant Surgeon

J. W. CLEWS, M.B.CH.B., Clinical Assistant
The present survey attempted to define objective criteria whereby patients likely to suffer recurrent calculi could be identified. Radiological examination is commonly used as a routine check in stone clincs to deteot unexpected stone formation which may require intervention or further investigation. The value of such examinations has not been clearly shown.

\section{Patients and Methods}

A total of 305 patients were included in the survey, which was carried out retrospectively. All the patients had passed a stone or had unequivocal radiological evidence of a urinary calculus and had presented in the 10-year period 1962-71. During the period of this survey no patient was discharged from the clinic and the default rate was less than $2 \%$.

Biochemical investigation of urine and serum is now performed on all patients, though early in the series this was not always done on patients with solitary stones. Serum urea and electrolytes, calcium (three non-occluded venous samples) uric acid, creatinine, and plasma proteins were estimated. Urinary calcium excretion was assessed on three consecutive days on the routine ward diet. Normal ranges were: serum calcium 8.5 to $10.5 \mathrm{mg} / 100 \mathrm{ml}$; urine calcium below $300 \mathrm{mg} / 24$ hours. Urine was examined bacteriologically in all cases at the time of presentation and any infection was treated with antibiotics as indicated by culture. Intravenous pyelography was performed on presentation to establish the exact site of the stones and also to detect anatomical abnormalities of the urinary traot. All available stones passed or removed surgically were analysed qualitatively.

Outpatient visits were at three- to 18 -month intervals depending on the presence or absence of symptoms, their duration, and the site of the stones. At each visit a clinical appraisal of the symptoms was made and either a plain $x$ ray film or an intravenous pyelogram was taken. The value of these investigations was assessed by estimating the number of clinically unexpected findings and the treatment indicated by these. 


\section{Results}

Of the 305 patients $218(71.5 \%)$ were male and $87(28.5 \%)$ were female. The average age at presentation was 44.0 years (males 46.0 years, females $41 \cdot 1$ years). The period of followup varied from 1 to 36 years, with a mean of 5.1 years.

Altogether 123 patients had stones confined to the left side, 124 had stones only on the right, and 54 had bilateral stones. In the remaining four patients the site of origin could not be determined, as stones were passed without lateralizing symptoms and no further calculi formed. A total of 195 patients $(63.9 \%)$ had a solitary stone and $110(36.1 \%)$ had multiple or recurrent stones (68 patients had two, 29 had three, 4 had four, and 9 had five or more); 101 calculi ( $20 \%$ ) were asymptomatic.

Biochemical Findings (table I).-Altogether 188 patients had a full analysis of the serum and urine and 27 had analysis of the serum only; the remaining 90 patients were not investigated. Of those fully studied $43(22.9 \%)$ were shown to have a biochemical abnormality (table I). Of the 110 patients with more than one episode of calculus disease 77 had a full biochemical analysis; of these, 28 (36.4\%) had an abnormality-23 had hypercalciuria alone, 2 had hyperparathyroidism, 2 had renal tubular acidosis, and 1 had cystinuria. Of the 195 patients with a solitary episode 111 had a full biochemical investigation; of these, 15 (13.5\%) had an abnormality-all had hypercalciuria. No abnormality was found in those who had only their serum examined.

TABLE I-Results of Biochemical Investigation of 305 Patients with Proved Urinary Calculi

\begin{tabular}{|c|c|c|c|}
\hline $\begin{array}{l}\text { Investi- } \\
\text { gation }\end{array}$ & Result & $\begin{array}{l}\text { No. with } \\
\text { One Episode }\end{array}$ & $\begin{array}{l}\text { No. with } \\
\text { Multiple Episodes }\end{array}$ \\
\hline $\begin{array}{c}\text { Urine and } \\
\text { serum }\end{array}$ & $\begin{array}{l}\text { Abnormal } \\
\text { Normal }\end{array}$ & $\begin{array}{l}15 \text { (15 hypercalciuria) } \\
96\end{array}$ & $\begin{array}{l}28 \text { (23 hypercalciuria, } \\
2 \text { hyperparathyroidism, } \\
2 \text { renal tubular acidosis. } \\
1 \text { cystinuria) } \\
49\end{array}$ \\
\hline $\begin{array}{c}\text { Serum } \\
\text { only }\end{array}$ & $\begin{array}{l}\text { Abnormal } \\
\text { Normal }\end{array}$ & $\begin{array}{r}0 \\
12\end{array}$ & $\begin{array}{r}0 \\
15\end{array}$ \\
\hline None & & 72 & 18 \\
\hline \multicolumn{2}{|c|}{ Total patients } & 195 & 110 \\
\hline
\end{tabular}

Bacteriological Findings (table II).-At the time of presentation $79(25.9 \%)$ patients had infected urine. The infection rate in females $(51.7 \%)$ was much higher than in males $(15.6 \%)$. There was no significant difference in the incidence of infection between those with a solitary episode $(27 \cdot 2 \%)$ and those with multiple episodes $(23.6 \%)$.

TABLE II-Prevalence of Urinary Infection at Time of Presentation

\begin{tabular}{|c|c|c|c|c|}
\hline \multicolumn{2}{|c|}{$\begin{array}{l}\text { Bacteriological } \\
\text { Culture: }\end{array}$} & $\begin{array}{c}\text { No. with } \\
\text { One Episode }\end{array}$ & $\begin{array}{l}\text { No. with } \\
\text { Multiple } \\
\text { Episodes }\end{array}$ & $\begin{array}{c}\text { Total } \\
\text { Patients }\end{array}$ \\
\hline $\begin{array}{l}\text { Infected } \\
\text { Non-infected }\end{array}$ & $\therefore$ & $\begin{aligned} 53 & (27 \cdot 2 \%) \\
142 & (72.8 \%)\end{aligned}$ & $\begin{array}{ll}26 & (23.6 \%) \\
84 & (76.4 \%)\end{array}$ & $\begin{aligned} 79 & (25.9 \%) \\
226 & (74 \cdot 1 \%)\end{aligned}$ \\
\hline Total pat & & $195(100 \cdot 0 \%)$ & $110(100 \cdot 0 \%)$ & $305(100 \cdot 0 \%)$ \\
\hline
\end{tabular}

TABLE III-Abnormalities found on Intravenous Pyelography

\begin{tabular}{|c|c|c|c|}
\hline & & $\begin{array}{c}\text { No. with } \\
\text { One Episode }\end{array}$ & $\begin{array}{c}\text { No. with } \\
\text { Multiple Episodes }\end{array}$ \\
\hline 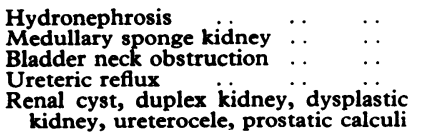 & $\begin{array}{l}\cdots \\
\cdots \\
\cdots \\
\cdots\end{array}$ & $\begin{array}{l}3 \\
4 \\
5 \\
2 \\
1 \text { each }\end{array}$ & $\begin{array}{l}4 \\
2\end{array}$ \\
\hline Total patients & & $19(9 \cdot 7 \%)$ & $6\left(5 \cdot 5^{0}\right)$ \\
\hline
\end{tabular}

Anatomical Findings (table III).-Intravenous pyelography was performed on all patients at the time of presentation. Twenty-five abnormalities were found, including seven cases of hydronephrosis and six of medullary sponge kidney. The other abnormalities are shown in table III.

Stone Analysis (table IV).-Analysis of 164 stones from 154 patients failed to show a composition which was more common in multiple stones than in solitary stones.

Surgical Treatment (table V). - Surgical treatment was required by 143 patients (46.9\%) and 175 operations were performed. Altogether 120 patients had one operation, 18 had two, 4 had three, and 1 patient had seven. There was no operative montality. The commonest operations were pyelolithotomy (42) and ureterolithotomy (35). Operations were performed on $50.3 \%$ of the patients with a solitary stone and on $40.9 \%$ of the patients with multiple stones.

Follow-up.- Of the $1,835 x$-ray examinations performed (table VI) 538 were for symptoms. In only 98 of the remaining 1,297 was there an unexpected finding (table VII)-50 showed a new stone that had developed asymptomatically, 1 showed an asymptomatic obstruction, and 47 showed that

TABLE IV-Percentage Frequency of Various Radicals in 164 Stones Analysed

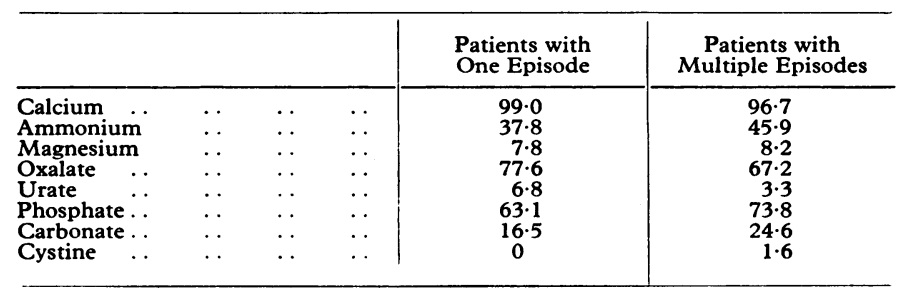

TABLE V-Operation performed on 143 Patients

\begin{tabular}{|c|c|c|c|}
\hline & $\begin{array}{c}\text { Patients with } \\
\text { One Episode } \\
(\mathbf{n}=98)\end{array}$ & $\begin{array}{l}\text { Patients with } \\
\text { Multiple Fpisodes } \\
(\mathrm{n}=45)\end{array}$ & Total \\
\hline $\begin{array}{l}\text { Upper pole nephrectomy } \\
\text { Lower pole nephrectomy } \\
\text { Nephrectomy } \ldots \\
\text { Nephrolithotomy } \ldots \\
\text { Pyelolithotomy } \ldots \\
\text { Ureterolithotomy } \\
\text { Dormia extraction } \\
\begin{array}{l}\text { Prostatectomy } \\
\text { Vesicolithotomy }\end{array} \\
\begin{array}{l}\text { Litholapaxy } \\
\text { Lithola }\end{array} \\
\text { Meatotomy } \\
\text { Urethral extraction } \\
\text { Implantation of ureter } \\
\text { Parathyroidectomy }\end{array}$ & $\begin{array}{r}4 \\
8 \\
18 \\
5 \\
26 \\
15 \\
16 \\
3 \\
2 \\
6 \\
1 \\
1\end{array}$ & $\begin{array}{r}3 \\
10 \\
9 \\
4 \\
16 \\
20 \\
6\end{array}$ & $\begin{array}{r}7 \\
18 \\
27 \\
9 \\
42 \\
35 \\
22 \\
3 \\
2 \\
6 \\
1 \\
1 \\
1 \\
1\end{array}$ \\
\hline
\end{tabular}

TABLE VI-Number of Radiological Examinations performed Routinely or for Symptoms

\begin{tabular}{|c|c|c|c|c|c|c|}
\hline \multirow{2}{*}{\multicolumn{3}{|c|}{ Patients with: }} & \multicolumn{2}{|c|}{ Routine } & \multicolumn{2}{|c|}{ For Symptoms } \\
\hline & & & U.T. & I.V.P. & U.T. & I.V.P. \\
\hline $\begin{array}{l}\text { One episode } \\
\text { Multiple episodes }\end{array}$ & $\therefore$ & $\begin{array}{l}\ldots \\
\cdots\end{array}$ & $\begin{array}{l}713 \\
490\end{array}$ & $\begin{array}{l}38 \\
56\end{array}$ & $\begin{array}{l}84 \\
91\end{array}$ & $\begin{array}{l}213 \\
150\end{array}$ \\
\hline Total & & & \multicolumn{2}{|c|}{$1,297(71 \%)$} & \multicolumn{2}{|c|}{$538(29 \%)$} \\
\hline
\end{tabular}

U.T. $=$ Straight film of urogenital tract. I.V.P. = Intravenous pyelogram.

TABLE VII-Unexpected Abnormalities found on Routine Radiological Examination

\begin{tabular}{c|c|c|c}
\hline & $\begin{array}{c}\text { No. in Patients with } \\
\text { One Episode }\end{array}$ & $\begin{array}{c}\text { No. in Patients with } \\
\text { Multiple Episodes }\end{array}$ & Total \\
\hline New stone .. & $\ldots$ & $4^{*}$ & 46 \\
Known stone gone .. & 12 & 35 & 50 \\
Obstruction .. & 0 & 1 & 47 \\
\hline Total & 16 & 82 & 98 \\
\hline
\end{tabular}

* Incidental findings of unrelated radiological examination-for example, barium meal. 
known stones had been passed without symptoms. Three patients had an operation because of these findings. Two had stones in functionless kidneys and one developed an obstructed kidney without symptoms.

\section{Discussion}

The prevalence of urinary calculi is rising and thus the burden on clinios will increase. The function of follow-up clinics is to detect early recurrence of stones and prevent possible renal damage. A method of identifying patients likely to produce recurrent stones would be ideal. For this purpose most centres perform biochemical screening of the serum and urine, bacteriological examination of the urine, and intravenous pyelography to identify abnormalities.

This survey was performed to select those criteria that would be most valuable in identifying recurrent stone formers. Of the patients examined $32.5 \%$ with recurrent stones suffered from hypercalciuria, whereas only $13.5 \%$ of those with solitary stones had this disorder. Though this difference is marked it is of little value in prospectively determining which patients should be followed, at $67.5 \%$ of those with recurrent stones apparently had normal urinary calcium excretion. Estimation of the serum calcium alone seemed to be of no value. In only two patients was this abnormal and both of these also had hypercalciuria. Therefore as a routine screening test of calcium metabolism urinary excretion is better than serum estimation.

The serum urea, creatinine, and plasma protein levels, though indicating a degree of renal damage in some patients, were of no value in predicting the recurrent stone formers. Urinary infection was present in a quanter of the patients at the time of presentation. The infection rate was higher in females than in males and similar in those with solitary and multiple stones. Nearly all patients had sterile urine after antibiotic therapy and removal or passage of the stone. Urinary infection seems to be an effect rather than a cause of urinary calculi in these patients and, though obviously needing careful follow-up, infection gives no lead in detecting those patients at risk from recurrent stones.

Pyelographic abnormalities were found in $19(9.7 \%)$ patients with one episode and only $6(5.5 \%)$ patients with multiple episodes. Though the figures are small anatomical abnormalities shown pyelographically do not allow the selection of patients with a propensity to form stones.

Stone composition was analysed qualitatively in 154 patients and found to be valueless in selecting the patients at risk of recurrence.

Operative treatment for urinary calculi may be thought to predispose to recurrent stone formation because a possible nidus is left in the urinary tract and patients with rapidly forming stones may be more likely to need surgery. Of the 143 patients who were operated on 98 had a solitary stone
(50.3\% of the 195 patients) and 45 had multiple stones (40.9\% of the 110 patients). Patients who have had surgery, therefore, do not seem to be at any more risk of forming stones than those managed conservatively.

In conclusion the screening investigations performed do not aid the selection of patients in whom recurrence is likely.

Obviously some patients, such as those with a degree of renal impairment, those with persistent urinary infection, especially in the presence of congenital abnormality or a stone, and those who have proved their ability to form recurrent stones, may require supervision. The latter group, however, may not necessarily be especially at risk for, as Williams (1968) has shown and we have verified, the number of patients in each group decreases as the number of stones increases. Most patients could without detriment be discharged from follow-up after the initial episode is controlled and asked to return if symptoms recur.

Most follow-up clinics undertake regular radiological examination of patients with urinary calculi. In this series 1,835 $x$-ray examinations were performed, an average of 6.0 per patient in a mean follow-up period of 5.1 years. Most of the straight films were routine, whereas most pyelograms were performed because of symptoms of pain, loin discomfont, or haematuria.

Altogether 98 unexpected findings were detected in 78 patients. These were either a new stone appearing or a known stone disappearing without symptoms (table VII). In one case a stone being observed regularly by straight films was found to have obstruoted a previously functioning kidney without symptoms. This shows the false sense of security given by regular films which show no change in the size or site of a stone.

Routine radiology is expensive and time-consuming and in this series affected the management in only one case. It seems that to subject all patients who have had urinary stones to regular radiological examination has little to offer.

It seems reasonable that patients without complications could be discharged from follow-up after their initial episode has settled and investigation is complete. Such patients could be asked to return when and if symptoms recur, as at that stage funther radiological examination has something to offer.

Requests for reprints should be sent to S. I. A. Powis, Department of Surgery, Queen Elizabeth Hospital, Birmingham 15.

\section{References}

Ahlgren, S., and Lorsted, M. (1965). Acta Chirurgica Scandinavica, 130, 354. Baker, R., and Connolly, J. P. (1956). Fournal of the American Medical Association, 160, 1106.

Garvey, F. K., and Boyce, W. H. (1956). fournal of the International College of Surgeons, 25, 310 .

Larsen, J. F., and Philip, J. (1962). Urologia Internationalis, 13, 53.

Williams, R. E. (1968). In Proceedings of the Renal Stone Research Symposium, ed. A. Hodgkinson and B. E. C. Nordin, p. 65. London, Churchill. 